\title{
Parameter analisis voltammetri pulsa diferensial elektrode grafit pensil untuk penentuan kadmium
}

\author{
Marlina Karundeng ${ }^{* a}$, Yeni Wahyuni Hartati ${ }^{b}$ \\ a Ilmu Kimia FMIPA, Universitas Negeri Manado, Tondano, 95619, Indonesia \\ b Ilmu Kimia FMIPA, Universitas Padjajaran, Sumedang, 45363, Indonesia
}

\begin{tabular}{l} 
I N F O A R T I K E L \\
\hline Diterima 19 Juli 2017 \\
Disetujui 21 Agustus 2017 \\
\\
\hline Key word: \\
Cadmium, \\
Voltammetry, \\
Graphite \\
\hline Kata kunci: \\
Kadmium, \\
Voltammetri, \\
Grafit \\
\hline
\end{tabular}

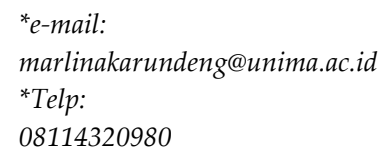

\begin{abstract}
A B S T R A T
Cadmium $(\mathrm{Cd})$ is one of the most important non-essential heavy metals, but can continue to increase in the environment. Bioaccumulative cadmium poisoning may cause kidney disease, stomach disorders, brittle bones, haemoglobin decline, and tooth pigmentation. Therefore, an analytical method for determining cadmium content should be developed. Methods for the determination of cadmium metal content that has been widely used is the method of AAS and ICP-AES method. With comparable sensitivity and selectivity, electrochemical methods such as voltammetry have been widely used as an interesting method for determining cadmium content, the instrumentation in this method is simpler than that of AAS and ICP-AES. The purpose of this study was to develop a method of voltammetry in determining cadmium using graphite pencil as a working electrode and parameter analysis of this method for cadmium quantification. The results of this study indicate that the voltammetric method using graphite pencil electrode can detect cadmium (II), with detection limit of $0.8 \mathrm{ppm}$, quantification limit of $2.8 \mathrm{ppm}$, linearity range from 2.8 to $4.8 \mathrm{ppm}$, and an accuracy of $0.21-0.58 \%$.
\end{abstract}

\section{A B S T R A K}

Kadmium (Cd) adalah salah satu logam berat non-esensial, yang relatif kecil, tetapi dapat terus meningkat di lingkungan, keracunan kadmium bersifat bioakumulatif dapat menyebabkan penyakit ginjal, gangguan perut, tulang rapuh, penurunan hemoglobin, dan pigmentasi gigi. Oleh karena itu metode analisis untuk menentukan kandungan kadmium harus dikembangkan. Metode untuk penentuan kandungan logam kadmium yang telah banyak digunakan adalah metode AAS dan metode ICP-AES. Dengan sensitivitas dan selektivitas yang sebanding, metode elektrokimia seperti voltammetri telah banyak digunakan sebagai metode yang menarik untuk menentukan kadar kadmium, instrumentasi pada metode ini lebih sederhana dibandingkan dengan metode AAS dan ICP-AES. Tujuan dari penelitian ini adalah untuk mengembangkan metode voltammetri dalam menentukan kadmium menggunakan pensil grafit sebagai elektroda kerja dan parameter analisis metode ini untuk kuantifikasi kadmium. Hasil penelitian ini menunjukkan bahwa metode voltammetri menggunakan pensil grafit elektroda dapat mendeteksi kadmium (II), dengan batas deteksi 0,8 ppm, batas kuantifikasi 2,8 ppm, rentang linearitas dari 2,8 menjadi 4,8 ppm, dan akurasi 0,21-0,58\%.

\section{Pendahuluan}

Indonesia memiliki potensi sumber daya perikanan yang besar, salah satunya berasal dari sumber daya perikanan laut. Namun, oleh FDA (Food and Drug Administration) melaporkan dari tahun 2001-2005 ada 350 penolakan pada produk ikan jenis tuna dari Indonesia, salah satu penyebab adalah karena kandungan logam berat, diantaranya kadmium yang melebihi ambang batas [1]. Di Indonesia oleh Badan 
Standar Nasional juga melaporkan kandungan kadmium pada ikan predator termasuk di dalamnya ikan jenis tuna mencapai hingga 0,6 $\mathrm{mg} / \mathrm{kg}$, sedangkan batas maksimum cemaran logam kadmium dalam pangan khususnya tuna adalah $0,5 \mathrm{mg} / \mathrm{kg}$ [2]. Bahan makanan yang tercemar logam berat, seperti kadmium menjadi tidak aman bagi konsumen karena akan mengganggu proses fisiologis dalam tubuh dan dapat mengakibatkan kerusakan DNA. Telah dipelajari bahwa Interaksi antara ion logam dengan DNA akan mengubah fungsi dan struktur material genetik [3]. Penyakit ginjal, gangguan lambung, rapuh tulang, penurunan hemoglobin, dan pigmentasi gigi adalah penyakit-penyakit yang disebabkan oleh keracunan kadmium [4]. Oleh karena itu metode analisis untuk mengetahui kandungan kadmium perlu terus dikembangkan.

Berbagai metode untuk penentuan kandungan logam kadmium yang telah banyak digunakan diantaranya adalah metode AAS [510], metode lain yaitu ICP-AES [11-15]. Metode AAS dan ICP-AES ini dapat mendeteksi kandungan kadmium dalam level ppm, namun instrumennya kurang sederhana, periode pengukuran yang panjang dan membutuhkan biaya yang mahal Teknik lain yang sudah dicoba untuk menentukan kadmium adalah elektrokimia yaitu voltammetri

Voltammetri adalah metode elektrokimia yang mengamati hubungan arus dengan potensial. Dari beberapa penelitian yang telah dilakukan untuk menentukan kadmium dengan metode ini, masih banyak yang menggunakan tetes raksa sebagai elektrode kerja [16]. Meskipun elektrode ini memiliki keunggulan seperti reprodusibilitas yang tinggi, dan permukaan yang dapat diperbaharui secara kontinyu, namun kekurangan elektrode ini yaitu bersifat toksik [17]. Grafit adalah alotrop karbon dapat dijadikan elektrode karena sifatnya yang dapat menghantar arus listrik. Sifatnya yang rapuh menjadi alasan grafit ini digunakan sebagai bahan pengisi pensil [18]. Elektrode grafit adalah salah satu elektrode padat yang memiliki keunggulan seperti rentang potensial yang luas dibanding elektrode raksa, murah, dan ramah lingkungan[17]. Berdasarkan latar belakang penelitian di atas, dalam penelitian ini akan dikembangkan metode penentuan kadmium secara voltammetri menggunakan grafit pensil sebagai elektrode kerja dan menentukan parameter analisisnya.

\section{Bahan dan Metode}

Bahan-bahan yang digunakan dalam penelitian ini adalah asam asetat glasial, natrium asetat, asam nitrat, asam perklorat, hidrogen peroksida, kadmium nitrat (semua bahan berkualitas pro analisis dan dibeli dari Merck), dan akuabides. Alat yang digunakan adalah pensil rotring, pensil pilot ENO $2 \mathrm{~B}$ dengan panjang $30 \mathrm{~mm}$ dan diameter $0,5 \mathrm{~mm}$, pelat pemanas, Potensiostat Metrohm ${ }^{\circledR} \mu$ Autolab type III, pH meter, pipet mikro 20-100 $\mu \mathrm{L}$ dan alatalat gelas, seperti labu ukur, gelas ukur, gelas kimia, batang pengaduk, dan lain-lain.

Metode penelitian yang dilakukan dimulai dari kegiatan merangkai alat, pengukuran voltammetri, optimasi kondisi voltammetri, menentukan parameter analitik.

\section{Merangkai Alat}

Sel voltammetri dirangkai dengan mengisi larutan elektrolit pendukung (buffer asetat) ke dalam bejana ukur dan ketiga elekrode yaitu elektrode kerja (grafit pensil); elektrode pembantu (Pt); dan elektrode pembanding $(\mathrm{Ag} / \mathrm{AgCl})$ dicelupkan ke dalam larutan tersebut. Sel ini kemudian dihubungkan pada sebuah potensiostat.

\section{Pengukuran Voltammetri}

1. Pengkondisian Larutan Buffer Asetat

Elektrode grafit pensil dipasang pada potensiostat dengan besar potensial $-1,0 \mathrm{~V}$ (terhadap $\mathrm{Ag} / \mathrm{AgCl}$ ) kemudian dicelupkan ke dalam bejana ukur yang berisi $6 \mathrm{ml}$ larutan buffer asetat $\mathrm{pH}$ 4. Mode diatur pada program voltammetri pulsa diferensial. Kondisi kerja diatur untuk pembacaan dari potensial $-1,0 \mathrm{~V}$ sampai 1,2 V. Pengerjaan yang sama dilakukan untuk buffer asetat $\mathrm{pH} 5,6$, dan 7 . Pengkondisian ini dilakukan untuk melihat respon larutan buffer yang telah dibuat, jika sudah baik akan memberi respon base line yang baik (tidak ada puncak) pada voltamogram [19]. 


\section{Menentukan Waktu Pretreatment Optimum}

Elektrode grafit pensil dipasang pada potensiostat kemudian dicelupkan ke dalam bejana ukur yang berisi $6 \mathrm{ml}$ larutan buffer asetat $\mathrm{pH}$ 6. Diatur waktu pretreatment 120 detik kemudian di-pretreatment pada potensial $-0,8 \mathrm{~V}$. Setelah elektrode grafit pensil di-pretreatment selanjutnya digunakan mengukur larutan yang mengandung kadmium 7 ppm. Dilakukan pengerjaan yang sama untuk variasi waktu pretreatment 300, 430, 600 detik. Hasil pengukuran berupa voltammogram dibandingkan tinggi arus puncaknya untuk mendapatkan waktu pretreatment optimum, yaitu pada arus puncak dengan tinggi maksimal.

\section{Menentukan $\mathrm{pH}$ Optimum}

Elektrode grafit pensil dipasang pada potensiostat dengan besar potensial $-1,0 \mathrm{~V}$ kemudian dicelupkan ke dalam bejana ukur yang berisi $3 \mathrm{ml}$ larutan buffer asetat $\mathrm{pH} 4$ dan 3 $\mathrm{ml}$ larutan standar kadmium $10 \mathrm{ppm}$. Mode diatur pada program voltammetri pulsa diferensial. Kondisi kerja diatur untuk pembacaan dari potensial $-1,0 \mathrm{~V}$ sampai 1,2 V. Pengerjaan yang sama dilakukan untuk buffer asetat $\mathrm{pH} 5$ dan 6, untuk mendapatkan $\mathrm{pH}$ optimum dari larutan buffer asetat dengan melihat sinyal arus puncak $\mathrm{E}_{1 / 2}$ (potensial setengah-gelombang) kadmium yang maksimal [19].

\section{Optimasi Waktu Deposisi}

Elektrode grafit pensil dipasang pada potensiostat dengan besar potensial $-1,0 \quad \mathrm{~V}$ kemudian dicelupkan ke dalam bejana ukur yang berisi $3 \mathrm{ml}$ larutan buffer asetat $\mathrm{pH}$ optimum dan $3 \mathrm{ml}$ larutan standar kadmium 10 ppm. Variasi waktu deposisi diatur pada 30, 60, 90, 120, dan 150 detik. Setelah periode 10 detik pengkondisian, voltammogram direkam dengan menerapkan voltammetri pulsa diferensial dengan rentang potensial dari $-1 \mathrm{~V}$ sampai 1,2 V. Waktu deposisi optimum adalah waktu dimana sinyal arus puncak reduksi paling maksimal [19].

\section{Optimasi Potensial Deposisi}

Elektrode grafit pensil dipasang pada potensiostat dengan besar potensial $-1,0 \quad \mathrm{~V}$ kemudian dicelupkan ke dalam bejana ukur yang berisi $3 \mathrm{ml}$ larutan buffer asetat $\mathrm{pH}$ optimum dan $3 \mathrm{ml}$ larutan standar kadmium 10 ppm. Variasi potensial deposisi diatur pada $-0,5$; $-0,6 ;-0,7 ;-0,8 ;-0,9 ;-1,0 ;-1,2 \mathrm{~V}$. Setelah periode 10 detik pengkondisian, voltammogram direkam dengan menerapkan voltammetri pulsa differensial dengan rentang potensial dari $-1 \mathrm{~V}$ sampai 1,2 V. Potensial deposisi optimum adalah potensial yang menunjukkan sinyal arus puncak reduksi yang maksimal [19].

\section{Optimasi Kecepatan Scan}

Elektrode grafit pensil disiapkan dipasang pada potensiostat dengan besar potensial $-0,1$ kemudian dicelupkan ke dalam bejana ukur yang berisi $3 \mathrm{ml}$ larutan buffer asetat $\mathrm{pH}$ optimum dan $3 \mathrm{ml}$ larutan standar kadmium 10 ppm. Variasi kecepatan scan yang akan dilakukan diatur pada 5, 10, 20, $30 \mathrm{mV} /$ detik. Kemudian voltammogram direkam dengan menerapkan voltammetri pulsa differensial dengan rentang potensial dari $-1 \mathrm{~V}$ sampai 1,2 V. Voltammogram yang diperoleh kemudian dibandingkan untuk memperoleh kecepatan scan optimum.

\section{Menentukkan Parameter Analitik}

1. Rentang Linearitas

Elektrode grafit pensil disiapkan dan dipasang pada potensiostat dengan besar potensial -1,0 V kemudian dicelupkan ke dalam bejana ukur yang diisi $3 \mathrm{ml}$ larutan buffer $\mathrm{pH}$ optimum dan $3 \mathrm{ml}$ larutan standar kadmium 1 ppm. Larutan ini kemudian diukur dengan analisis voltammetri pulsa diferensial pada rentang potensial dari $-1 \mathrm{~V}$ sampai $1,2 \mathrm{~V}$ dengan waktu dan potensial deposisi optimum. Dengan kondisi kerja yang sama, pengukuran dilakukan lagi pada variasi konsentrasi 2, 3, 4, 5, 6, 7, 8 ppm. Pengukuran untuk setiap konsentrasi dilakukan lima kali pengulangan.

\section{Batas Deteksi, Batas Kuantifikasi, dan Kecermatan}

Elektrode grafit pensil yang sudah dipretreatment pada waktu optimumnya dipasang pada potensiostat dengan besar potensial $-1,0 \mathrm{~V}$ kemudian dicelupkan ke dalam bejana ukur yang diisi larutan standar kadmium dengan variasi konsentrasi kurva baku yang linear 
dalam larutan buffer $\mathrm{pH}$ optimum, kemudian larutan dianalisis secara voltammetri pulsa diferensial pada rentang potensial dari $-1 \mathrm{~V}$ sampai $1,2 \mathrm{~V}$ dengan waktu dan potensial deposisi optimum. Setiap pengukuran dilakukan lima kali untuk perhitungan kecermatan.

\section{Hasil dan Pembahasan}

1. Voltamogram Kadmium Secara DPV Dengan Elektrode Grafit Pensil

Kemampuan dari elektrode grafit pensil ini dalam mendeteksi kadmium secara DPV dilihat dengan membandingkan hasil voltamogram pengukuran larutan blanko (buffer asetat $0,2 \mathrm{M}$ ) dan larutan analit (buffer asetat 0,2 $\mathrm{M}$ ditambah kadmium (II) 10 ppm). Hasil pengukuran ditunjukkan pada Gambar 1.

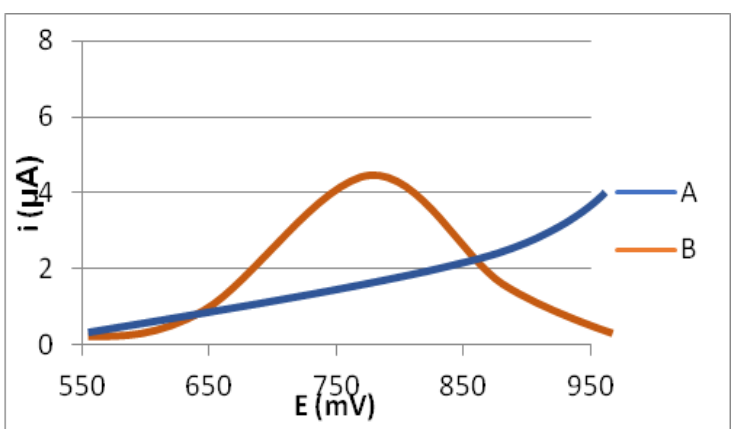

Gambar 1. Voltamogram pengukuran larutan (A) 0,2 M buffer asetat $\mathrm{pH}$ 5dan (B) kadmium

(II) 5 ppm dalam 0,2 M buffer asetat $\mathrm{pH}$ 5, kecepatan scan 0,01 V/detik, modulasi amplitudo $0,025 \mathrm{~V}$.

Gambar 1, menunjukkan bahwa voltamogram (A) buffer asetat tidak memberikan arus puncak pada elektrode grafit pensil, sedangkan pada voltamogram (B) kadmium (II) memberikan respon arus puncak pada elektrode grafit pensil di daerah potensial 0,771 $\mathrm{V}$ terhadap $\mathrm{Ag} / \mathrm{AgCl}(\mathrm{KCl} 3 \mathrm{M})$. Hal ini menunjukan bahwa kadmium (II) dapat teradsorpsi di permukaan elektrode grafit sehingga menghasilkan respon arus puncak pada pengukuran larutan yang mengandung kadmium (II). [19]

\section{Penentuan Waktu Pretreatment Optimum}

Pengaruh waktu pretreatment dipelajari dengan membandingkan voltamogram hasil pengukuran larutan analit dalam buffer asetat, setelah elektrode grafit pensil di pretreatment terlebih dahulu dengan waktu pretreatment yang divariasikan. Data hasil pengukuran ditunjukan pada Tabel 1 dan Gambar 2.

Tabel 1. Data Hasil Pengukuran dengan Variasi Waktu Pretreatment

\begin{tabular}{llllllll}
\hline $\begin{array}{l}\text { Waktu } \\
\text { Pretreat- }\end{array}$ & $\begin{array}{l}\text { Potensial } \\
(\mathrm{mV})\end{array}$ & $\begin{array}{l}\text { Tinggi Arus } \\
(\mu \mathrm{A})\end{array}$ & & & & & \multicolumn{2}{l}{$\begin{array}{l}\text { Tinggi arus } \\
\text { rata-rata } \\
\text { ment }(\mathrm{s})\end{array}$} & 1 & 2 & 3 & 4 & 5 & $(\mu \mathrm{A})$ \\
\hline 120 & 0,787 & 0,228 & 0,208 & 0,226 & 0,228 & 0,227 & $0,2234 \pm 0,008$ \\
300 & 0,774 & 1,167 & 1,167 & 1,508 & 2,002 & 1,167 & $1,4022 \pm 0,363$ \\
420 & 0,777 & 0,185 & 0,305 & 0,304 & 0,184 & 0,304 & $0,2564 \pm 0,065$ \\
600 & 0,772 & 0,137 & 0,106 & 0,137 & 0,106 & 0,106 & $0,1184 \pm 0,016$ \\
\hline
\end{tabular}

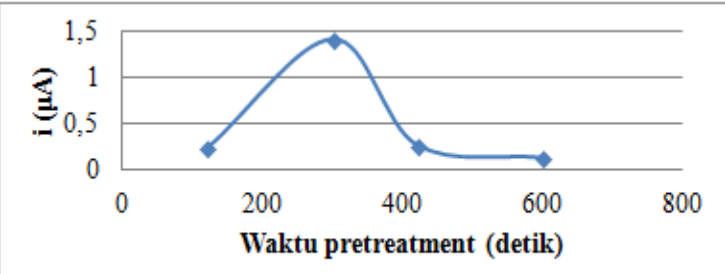

Gambar 2. Kurva hubungan tinggi arus puncak dengan lamanya waktu pretreatment

Dari Gambar 2 ditunjukkan bahwa tinggi puncak arus dipengaruhi oleh lamanya waktu pretreatment yang diberikan pada elektrode grafit pensil sebelum dipasang pada larutan ukur. Dari data hasil pengukuran diperoleh waktu pretreatment optimum adalah 300 detik. Kondisi optimum ini digunakan pada prosedur selanjutnya untuk penentuan kadmium (II) secara DPV dengan elektrode grafit pensil.

\section{Penentuan $\mathrm{pH}$ Optimum}

Kondisi $\mathrm{pH}$ sangat mempengaruhi reaksi kimia antara ion kadmium (II) dengan grafit. Pada kondisi $\mathrm{pH}$ yang baik diharapkan semakin banyak ion kadmium (II) dapat teradsorpsi di permukaan elektrode grafit sehingga menghasilkan arus puncak yang tinggi pada saat pengukuran. Pengaruh $\mathrm{pH}$ dipelajari dengan membandingkan voltamogram hasil pengukuran larutan analit dalam buffer asetat dengan kondisi $\mathrm{pH}$ yang divariasikan. Hasil pengukuran ditunjukkan pada Gambar 3 dan data hasil pengukuran ditunjukan pada Tabel 2. Kurva hubungan antara kondisi $\mathrm{pH}$ larutan analit terhadap tinggi puncak ditunjukkan pada Gambar 4. 
Tabel 2. Hasil Pengukuran Larutan Kadmium(II) 5 ppm dalam 0,2 M Buffer Asetat dengan variasi $\mathrm{pH}$

\begin{tabular}{|c|c|c|c|c|c|c|c|}
\hline \multirow[b]{2}{*}{$\mathrm{pH}$} & \multirow{2}{*}{$\begin{array}{l}\text { Potensial } \\
\text { (V) }\end{array}$} & \multicolumn{5}{|c|}{$\operatorname{Arus}(\mu \mathrm{A})$} & \multirow{2}{*}{ Arus rata-rata } \\
\hline & & 1 & 2 & 3 & 4 & 5 & \\
\hline 4 & 0,761 & 3,164 & 6,631 & 3,998 & 6,549 & 3,582 & $4,785 \pm 1,675$ \\
\hline 5 & 0,771 & 4,529 & 3,519 & 5,761 & 3,689 & 4,529 & $4,405 \pm 0,889$ \\
\hline 6 & 0,771 & 7,518 & 3,674 & 5,761 & 7,108 & 6,274 & $6,067 \pm 1,504$ \\
\hline 7 & 0,773 & 0,13 & 0,265 & 0,274 & 0,329 & 0,265 & $0,252 \pm 0,073$ \\
\hline
\end{tabular}

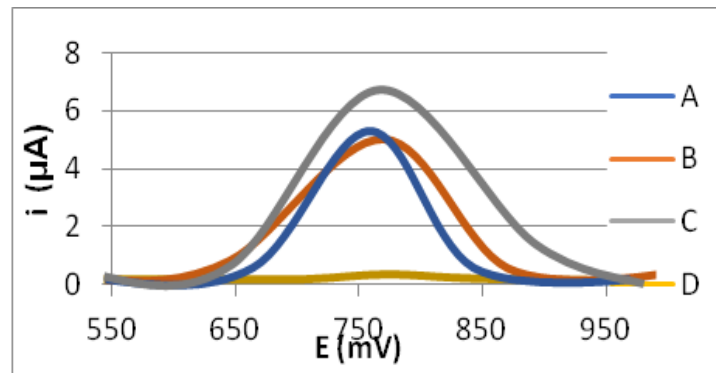

Gambar 3. Voltamogram pengukuran larutan kadmium (II) 5 ppm dalam 0,2 M buffer asetat dengan variasi $\mathrm{pH}$ (A) 4, (B) 5, (C) 6, dan (D) 7.

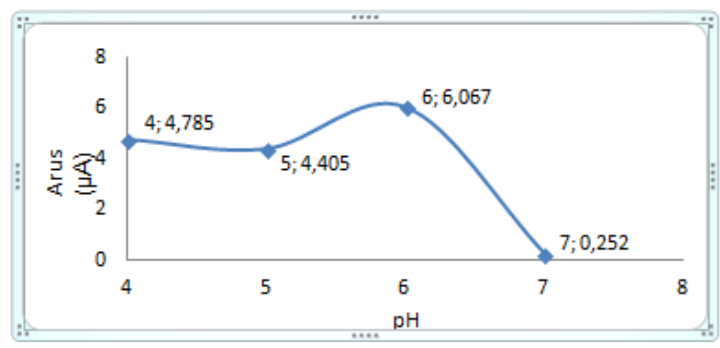

Gambar 4. Kurva hubungan antara kondisi $\mathrm{pH}$ larutan analit terhadap tinggi puncak kadmium (II) 5 ppm.

Pada Gambar 4 terlihat bahwa tinggi arus puncak kadmium (II) sangat dipengaruhi oleh pH larutan buffer. Pada larutan buffer $\mathrm{pH} 4$ memberikan respon arus puncak yang rendah karena pada keadaan itu larutan analit dalam keadaan terlalu asam dengan jumlah proton $\left(\mathrm{H}^{+}\right)$ dalam larutan lebih banyak sehingga mengakibatkan permukaan elektrode grafit lebih banyak berikatan dengan proton $\left(\mathrm{H}^{+}\right)$ daripada dengan ion kadmium (II). Keadaan yang sama juga masih terjadi pada larutan analit dengan $\mathrm{pH}$ 5. Tinggi puncak optimum adalah pada $\mathrm{pH}$ 6, karena pada kondisi $\mathrm{pH}$ asam tersebut kadmium (II) berada dalam bentuk ion bebasnya dalam jumlah yang banyak sehingga ion kadmium (II) banyak yang terjebak di permukaan elektrode grafit dan memberikan respon arus puncak yang tinggi. Pada $\mathrm{pH} 7$ respon arus puncak menurun drastis karena dalam keadaan $\mathrm{pH}$ ini, ion kadmium (II) sangat sedikit yang teradsorpsi pada permukaan elektrode oleh kehadiran ion $\mathrm{OH}_{-}$. Pada $\mathrm{pH}$ tinggi ion logam akan lebih berikatan dengan ion $\mathrm{OH}^{-}$. Pada $\mathrm{pH}$ tertentu ion logam akan membentuk hidroksidanya dan mengendap [20]. Kondisi $\mathrm{pH}$ optimum untuk analisis kadmium (II) menggunakan elektrode grafit pensil sebagai elektrode kerja secara DPV adalah $\mathrm{pH}$ 6, pH optimum ini akan digunakan pada prosedur pengukuran selanjutnya. Pada kondisi $\mathrm{pH}$ optimum ini pengukuran kadmium (II) menggunakan elektrode grafit pensil secara DPV memberi respon puncak arus pada daerah potensial $0,771 \mathrm{~V}$ terhadap $\mathrm{Ag} / \mathrm{AgCl}(\mathrm{KCl} 3 \mathrm{M})$ [19].

\section{Penentuan Waktu Deposisi Optimum}

Pada tahapan deposisi (prekonsentrasi), waktu deposisi sangat mempengaruhi bereaksinya ion kadmium (II) di permukaan elektrode grafit. Pengaruh waktu deposisi ini dipelajari dengan membandingkan voltammogram hasil pengukuran larutan yang mengandung kadmium 5 ppm dalam 0,2 M buffer asetat $\mathrm{pH} 6$ dengan waktu deposisi yang divariasikan. Data hasil pengukuran ditunjukkan pada Tabel 3 gambar voltammogramnya ditunjukkan pada Gambar 5, dan kurva hubungan puncak arus dengan variasi waktu deposisi, seperti yang ditunjukkan pada Gambar 6.

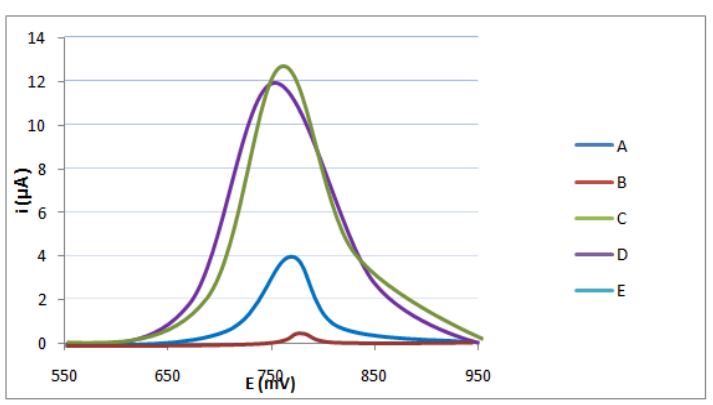

Gambar 5. Voltamogram hasil pengukuran kadmium 5 ppm dalam 0,2 M buffer asetat pH 6 dengan variasi waktu deposisi (A) $30 \mathrm{~s}$; (B) $60 \mathrm{~s}$; (C) $120 \mathrm{~s}$; (D) $90 \mathrm{~s}$; dan (E) $150 \mathrm{~s}$ 
Tabel 3. Data hasil pengukuran kadmium 5 ppm dalam 0,2 M buffer asetat pH 6

\begin{tabular}{|c|c|c|c|c|c|c|c|}
\hline \multirow{2}{*}{$\begin{array}{l}\text { Wak- } \\
\text { tu } \\
\text { Depo- } \\
\text { Depo } \\
\text { sisi }(s)\end{array}$} & \multirow{2}{*}{$\begin{array}{l}\text { Poten- } \\
\text { sial } \\
\text { (V) }\end{array}$} & \multicolumn{5}{|c|}{ Arus (uA) } & \multirow{2}{*}{$\begin{array}{l}\text { Arus Rata-rata } \\
\text { ( }(\mathrm{A} \mathrm{A})\end{array}$} \\
\hline & & 1 & 2 & 3 & 4 & 5 & \\
\hline 30 & 0,769 & 1,594 & 2,672 & 1,738 & 9,678 & 1,653 & $3,467 \pm 3,449$ \\
\hline 60 & 0,779 & 0,242 & 0,752 & 0,179 & 0,888 & 0,147 & $0,3116 \pm 0,052$ \\
\hline 90 & 0,762 & 4,042 & 10,8 & 13,932 & 13,351 & 12,546 & $10,934 \pm 4,029$ \\
\hline 120 & 0,752 & 11,704 & 10,293 & 12,912 & 14,75 & 14,077 & $12,414 \pm 6,407$ \\
\hline 150 & 0,757 & 0,172 & 2,848 & 0,14 & 0,122 & 0,158 & $0,688 \pm 1,207$ \\
\hline
\end{tabular}

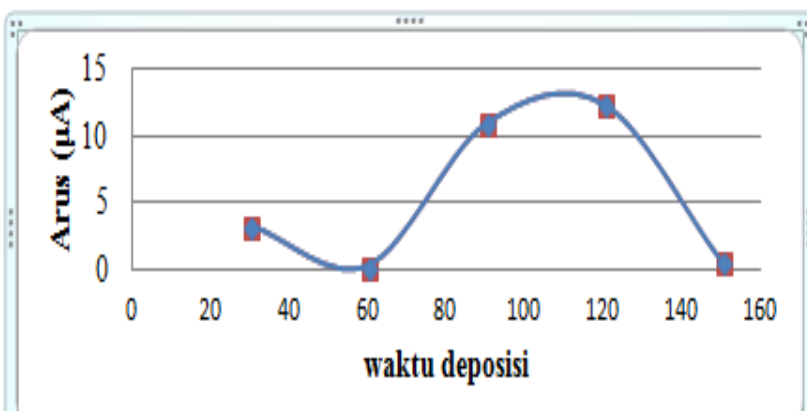

Gambar 6. Kurva Hubungan antara Waktu Deposisi terhadap Tinggi Arus Puncak Pengukuran Kadmium(II) 5 ppm dalam Larutan 0,2 M Buffer Asetat pH 6.

Gambar 6 menunjukkan bahwa lamanya waktu deposisi berpengaruh pada tinggi arus puncak kadmium (II). Tinggi arus puncak semakin meningkat pada waktu optimum yang semakin lama, disebabkan karena ion kadmium (II) yang berada pada permukaan elektrode grafit terkumpul dan terakumulasi sampai akhirnya jenuh karena seluruh ion kadmium (II) telah menempel di permukaan elektrode grafit. Dari hasil pengukuran diperoleh waktu deposisi optimum adalah 120 detik. Waktu deposisi optimum ini digunakan pada prosedur selanjutnya untuk penentuan kadmium (II) menggunakan elektrode grafit pensil secara DPV [19].

\section{Penentuan Potensial Deposisi Optimum}

Potensial deposisi diperlukan untuk mereduksi ion kadmium (II) menjadi kadmium di permukaan elektrode grafit. Pengaruh potensial deposisi ini dipelajari dengan membandingkan hasil voltammogram puncak arus dari larutan analit yang diukur dengan pemberian potensial deposisi yang divariasikan. Hasil pengukuran dapat dilihat pada Gambar 7, dan data hasil pengukuran pada Tabel 4 .

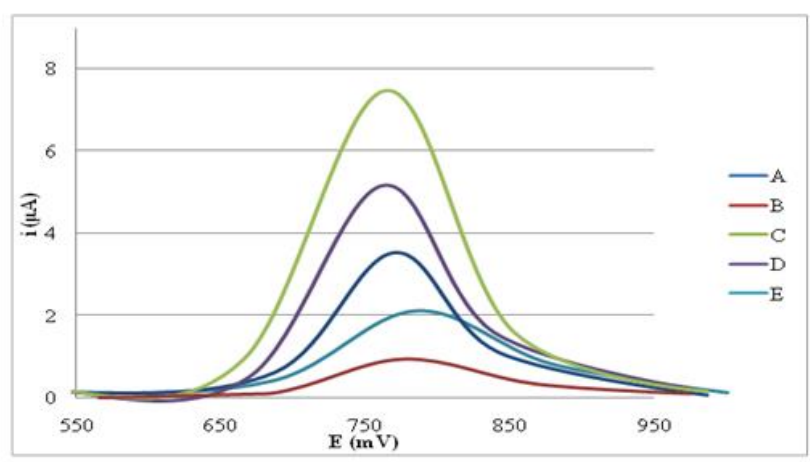

Gambar 7. Voltamogram hasil pengukuran kadmium 5 ppm dalam 0,2 $\mathrm{M}$ buffer asetat $\mathrm{pH}$ 6 dengan variasi potensial deposisi (A) $-0,5 \mathrm{~V}$; (B) -0,6 V; (C) -0,7 V; (D) -0,8 V; dan (E) 0, $9 \mathrm{~V}$.

Tabel 4. Data Hasil Pengukuran Kadmium 5 ppm dalam 0,2 M Buffer Asetat pH 6 denganVariasi Potensial Deposisi

\begin{tabular}{|c|c|c|c|c|c|c|c|}
\hline \multirow{2}{*}{$\begin{array}{l}\text { Poten- } \\
\text { sial } \\
\text { Depo- } \\
\text { sisi (V) }\end{array}$} & \multirow{2}{*}{$\begin{array}{l}\text { Poten- } \\
\text { sial } \\
\text { (V) }\end{array}$} & \multicolumn{5}{|c|}{$\begin{array}{l}\text { Arus } \\
(\mu \mathrm{A})\end{array}$} & \multirow{2}{*}{$\begin{array}{l}\text { Arus Rata-rata } \\
(\mu \mathrm{A})\end{array}$} \\
\hline & & 1 & 2 & 3 & 4 & 5 & \\
\hline$-0,5$ & 0,764 & 1,205 & 5,851 & 5,561 & 5,333 & 0,120 & $3.614 \pm 2,727$ \\
\hline$-0,6$ & 0,772 & 0,170 & 0,763 & 0,492 & 0,131 & 4,529 & $1,217 \pm 1,869$ \\
\hline$-0,7$ & 0,757 & 3,689 & 9,793 & 9,394 & 8,641 & 7,888 & $7,881 \pm 2,454$ \\
\hline$-0,8$ & 0,757 & 1,883 & 6,260 & 6,603 & 6,149 & 6,008 & $5,381 \pm 1,967$ \\
\hline$-0,9$ & 0,778 & 1,610 & 2,402 & 2,287 & 2,391 & 2,457 & $2,229 \pm 0,351$ \\
\hline
\end{tabular}

\section{Penentuan Kecepatan Scan Optimum}

Pada tahap pelucutan kembali (striping) tinggi arus puncak dan lebar puncak dipengaruhi oleh kecepatan scan. Pengaruh kecepatan scan dipelajari dengan membandingkan voltammogram hasil pengukuran larutan kadmium (II) dalam buffer asetat pH 6 dengan waktu deposisi 120 detik, potensial deposisi $-0,7 \mathrm{~V}$ dan kecepatan scan divariasikan. Hasil pengukuran ditunjukan pada Gambar 8, data hasil pengukuran ditunjukkan pada Tabel 5, dan kurva hubungan puncak arus dengan variasi waktu deposisi ditunjukkan pada Gambar 9. 


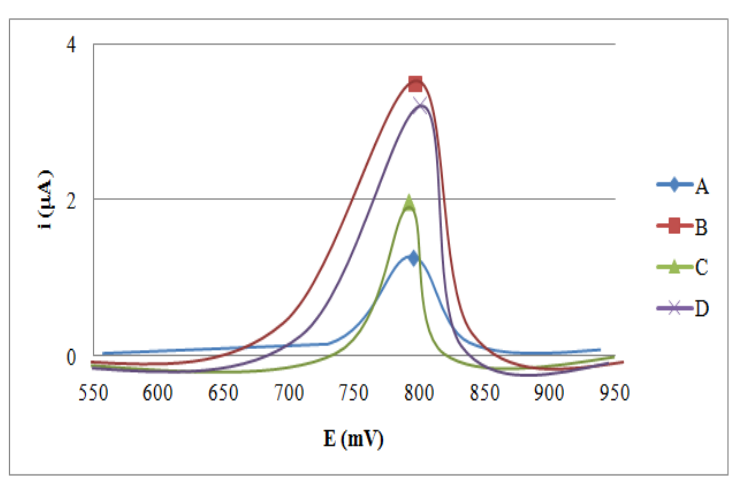

Gambar 8. Voltamogram hasil pengukuran kadmium 5 ppm dalam 0,2 M buffer asetat $\mathrm{pH}$ 6 dengan variasi kecepatan scan (A) 0,005 V/detik; (B) 0,01 V/detik; (C) 0,02 V/detik; dan (D) $0,03 \mathrm{~V} /$ detik.

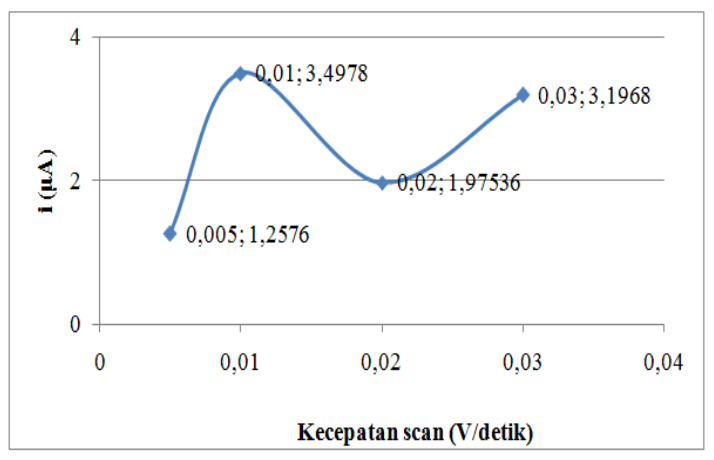

Gambar 9. Kurva hubungan antara kecepatan scan terhadap tinggi arus puncak pengukuran kadmium (II) 5 ppm dalam larutan 0,2 M buffer asetat $\mathrm{pH}$ 6, waktu deposisi 120 detik, potensial deposisi $-0,7 \mathrm{~V}$.

Tabel 5. Data Hasil Pengukuran Kadmium 5 ppm dalam 0,2 M Buffer Asetat pH 6 denganVariasi Kecepatan Scan

\begin{tabular}{|c|c|c|c|c|c|c|c|}
\hline \multirow{2}{*}{$\begin{array}{l}\text { Kece- } \\
\text { patan } \\
\text { scan } \\
\text { (V/det.) }\end{array}$} & \multirow{2}{*}{$\begin{array}{l}\text { Poten- } \\
\text { sial } \\
\text { (V) }\end{array}$} & \multicolumn{5}{|c|}{$\begin{array}{l}\text { Arus } \\
(\mu \mathrm{A}) \\
\end{array}$} & \multirow{2}{*}{$\begin{array}{l}\text { Arus Rata-rata } \\
(\mu \mathrm{A})\end{array}$} \\
\hline & & 1 & 2 & 3 & 4 & 5 & \\
\hline 0,005 & 0,795 & 0,896 & 1,235 & 1,304 & 1,445 & 1,408 & $1,257 \pm 0,2186$ \\
\hline 0,01 & 0,797 & 1,691 & 2,954 & 3,796 & 4,344 & 4,704 & $3,497 \pm 1,206$ \\
\hline 0,02 & 0,792 & 1,4818 & 1,8 & 2,172 & 2,22 & 2,203 & $1,975=0,325$ \\
\hline 0,03 & 0,801 & 2,989 & 3,575 & 3,382 & 3,123 & 2,915 & $3,196 \pm 0,276$ \\
\hline
\end{tabular}

Gambar 9 menunjukkan bahwa kecepatan scan mempengaruhi tinggi arus puncak dari kadmium (II). Arus yang dihasilkan sebanding dengan kecepatan elektrolisis yang terjadi pada permukaan elektrode. Dimana, elektrolisis yang berlangsung di permukaan elektrode adalah respon dari pemberian potensial. Semakin tinggi kecepatan scan yang diberikan maka kecepatan reaksi elektrolisis akan semakin cepat sehingga tinggi arus puncak akan semakin bertambah [21]. Voltammogram pada kecepatan scan 0,01 V/detik mengalami peningkatan tinggi arus puncak dibandingkan dengan arus puncak pada kecepatan scan 0,005 V/detik dan 0,002 V/detik, sehingga kecepatan scan 0,01 v/detik dipilih sebagai kecepatan scan optimum untuk prosedur selanjutnya.

\section{Penentuan Parameter Analitik}

7.1 Penentuan Daerah Konsentrasi Linear

Daerah konsentrasi linear elektrode grafit pensil untuk analisis kadmium (II) dipelajari untuk mengetahui daerah (rentang) konsentrasi yang memberi hubungan linear antara tinggi arus puncak dengan konsentrasi kadmium (II). Hasil pengukuran daerah konsentrasi linear ditunjukkan pada Gambar 10.

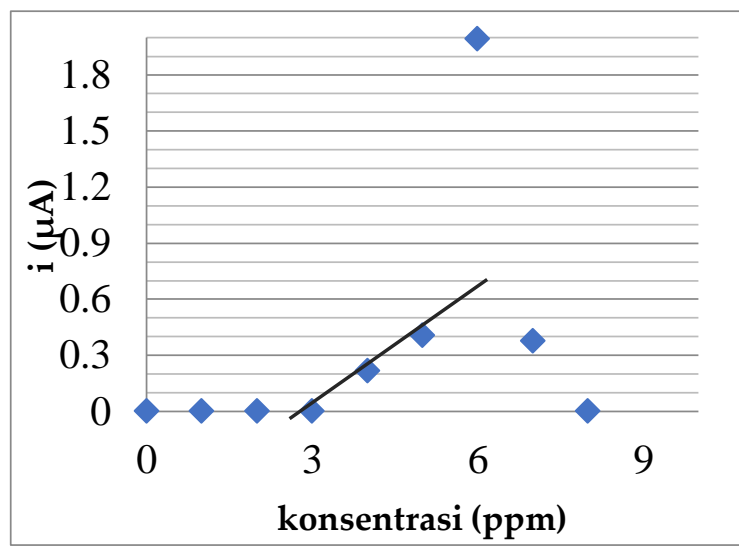

Gambar 10. Kurva hubungan konsentrasi larutan kadmium (II) terhadap tinggi arus puncak

Dari gambar 10 ditunjukkan bahwa daerah konsentrasi linear hanya berada pada konsentrasi 4 sampai 5 ppm. Pada konsentrasi 6 ppm tinggi arus puncak naik tajam tapi tidak lagi berada dalam rentang yang linear dengan konsentrasi 4 dan 5 ppm. Sehingga daerah konsentrasi linear yang dipilih untuk pengukuran kadmium (II) adalah 4 sampai 5 ppm.

\subsection{Kurva Kalibrasi Larutan Kadmium (II) untuk Metode Voltammetri \\ Pada pembuatan kurva kalibrasi untuk}


metode voltammetri menggunakan elektrode grafit pensil digunakan larutan kadmium (II) dengan konsentrasi 4,2;4,4;4,6; 4,8 ppm. Kemudian diukur sebanyak 5 kali untuk masing-masing konsentrasi. Hasil pengukuran kurva kalibrasi larutan kadmium (II) ditunjukkan pada Gambar 11 dan data tinggi arus puncak terhadap konsentrasi larutan kadmium (II) ditunjukkan pada Tabel 6 .

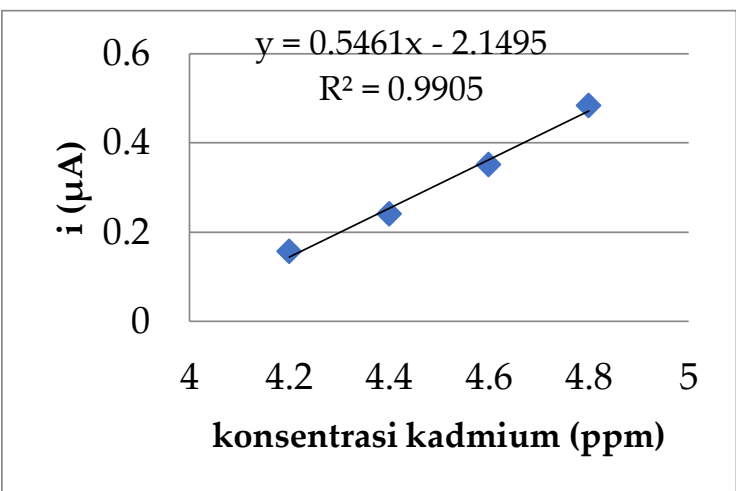

Gambar 11. Kurva kalibrasi larutan kadmium (II) menggunakan metode DPV dengan elektrode grafit pensil.

Tabel 6. Hasil pengukuran kurva kalibrasi larutan kadmium (II) secara DPV

\begin{tabular}{lllllll}
\hline $\begin{array}{l}\text { Konsen- } \\
\text { trasi } \\
(\mathrm{ppm})\end{array}$ & 1 & 2 & 3 & 4 & 5 & \multicolumn{3}{c}{$\begin{array}{c}\text { Arus } \\
(\mu \mathrm{A})\end{array}$} \\
\cline { 2 - 6 } rata $(\mu \mathrm{A})$
\end{tabular}

Dari Gambar 11 ditunjukkan bahwa terdapat hubungan garis lurus antara konsentrasi kadmium (II) dengan tinggi arus puncak, persamaan garis untuk kurva kalibrasi adalah $\mathrm{y}=0,546 \mathrm{x}-2,149$ dengan nilai $\mathrm{R} 2=0,99$. Setelah dilakukan pengujian rentang kepercayaan terhadap intersep (a), diperoleh rentang kepercayaan a dengan tingkat kepercayaan 95\% antara -9,630 hingga 5,331. Nilai a melewati titik 0 , maka persamaan regresinya berubah menjadi $y=0,069 \mathrm{x}$. Persamaan ini yang selanjutnya digunakan untuk menentukan kadar kadmium suatu sampel dengan cara mengukur tinggi arus puncak reduksi larutan kadmium (II).

\subsection{Batas Deteksi dan Batas Kuantifikasi}

Penentuan batas deteksi digunakan persamaan $\mathrm{y}=\mathrm{yb}+3 \mathrm{Sb}$. Maka diperoleh harga batas deteksi dari alat adalah 0,8 ppm. Batas kuantifikasi digunakan persamaan $\mathrm{y}=\mathrm{yb}+10$ $\mathrm{Sb}$, diperoleh harga batas kuantifikasinya adalah $2,8 \mathrm{ppm}$.

\subsection{Pembuktian Rentang Linearitas}

Dari hasil perhitungan diperoleh $\mathrm{t}$ uji $=$ 0,529 sedangkan $t$ tabel $=12,71$ sehingga dapat disimpulkan bahwa larutan standar dengan konsentrasi tertinggi $(4,8 \mathrm{ppm})$ termasuk ke dalam hubungan linear kurva kalibrasi dengan rentang linearitas 2,8-4,8 ppm.

\subsection{Penentuan Kecermatan}

Data hasil pengukuran untuk penentuan kecermatan ditunjukkan pada Tabel 7 . Pengukuran dilakukan dengan menggunakan variasi konsentrasi dari 4,2; 4,4; 4,6 dan 4,8 ppm, dengan pengulangan 5 kali untuk masingmasing konsentrasi. Rata-rata tinggi arus puncak dimasukkan ke dalam persamaan $\mathrm{y}=$ 0,06961 x hasilnya adalah kecermatan dari 0.21 $-0,58 \%$.

Tabel 7. Penentuan Kecermatan Metode Voltammetri Menggunakan Elektrode Grafit Pensil

\begin{tabular}{|c|c|c|c|c|}
\hline kons.std $(\mu)$ & $\operatorname{Ip}(\mu \mathrm{A})(\mathrm{y})$ & $\begin{array}{l}\text { rata2 kons terukur } \\
y=0,06961 x \\
X(\mu \mathrm{A})\end{array}$ & $\begin{array}{l}\text { simpangan } \\
\text { baku (Sb) }\end{array}$ & $\begin{array}{l}\text { kecematan } \\
\mathrm{sb} / \mathrm{x} .100 \%\end{array}$ \\
\hline 4,2 & 0,1562 & 2,243 & 0,527 & 0,234 \\
\hline 4,4 & 0,241 & 3,462 & 0,731 & 0,211 \\
\hline 4,6 & 0,351 & 5,048 & 2,955 & 0,585 \\
\hline 4,8 & 0,4836 & 6,947 & 1,735 & 0,249 \\
\hline
\end{tabular}

\section{Ucapan terimakasih}

Terima kasih kepada Pascasarjana MIPA UNPAD, Jurusan Kimia UNPAD, para Laboran Laboratorium Kimia Analitik UNPAD, dan semua pihak yang telah membantu dalam penyelesaian penelitian ini.

\section{Kesimpulan}

Berdasarkan hasil penelitian ini, maka dapat ditarik kesimpulan bahwa metode voltammetri menggunakan elektrode grafit pensil dapat mendeteksi kadmium, dan parameter analitik penentuan kadmium 
menggunakan metode voltammetri dengan elektrode grafit pensil sebagai berikut; batas deteksi 0,8 ppm, batas kuantifikasi 2,8 ppm, rentang linearitas 2,8 - 4,8 ppm, kecermatan $0,211-0,585 \%$.

\section{Daftar Pustaka}

1. Widiastuti, I. Analisis mutu ikan tuna selama lepas tangkap pada perbedaan preparasi dan waktu penyimpanan. Tesis, Institut Pertanian Bogor: Bogor, 2008.

2. Standar Nasional Indonesia Batas maksimum cemaran logam berat dalam pangan; SNI, 2009;

3. Oliveira, S. C. B.; Corduneanu, O.; Oliveira-Brett, A. M. In situ evaluation of heavy metal-DNA interactions using an electrochemical DNA biosensor. Bioelectrochemistry 2008, 72, 53-58.

4. Ratmini, N. A. Kandungan Logam Berat Timbal (Pb), Mercuri (Hg) Dan Cadmium (Cd) Pada Daging Ikan Sapu-Sapu (Hyposarcus Pardalis) Di Sungai Ciliwung, Stasiun Srengseng, Condet Dan Manggarai. Vis Vitalis 2009, 2.

5. Bruland, K. W.; Coale, K. H.; Mart, L. Analysis of seawater for dissolved cadmium, copper and lead: An intercomparison of voltammetric and atomic absorption methods. Mar. Chem. 1985, 17, 285-300.

6. Stafilov, T.; Jordanovska, V. Determination of cadmium in some vegetables produced in the area near the lead and zinc smelting plant in Veles, Macedonia. Ecol Prot. Env. 1997, 4, 35-38.

7. Wahab, A.; Latifah, J.; Sahetapy, J. Analisis Logam Berta Kadmium (Cd) dan Tembaga (Cu) pada Air Laut di Sekitar Tempat Pelelangan Ikan Kabupaten Sinjai Propinsi Sulawesi Selatan. Ichthyos 2004, 4, 29-32.

8. Chwastowska, J.; Skwara, W.; Sterlinska, E.; Dudek, J.; Dabrowska, M.; Pszonicki, L. GF AAS determination of cadmium, lead and copper in environmental materials and food products after separation on dithizone sorbent. Chem AnalWarsaw 2008, $53,887$.

9. Lubis, H.; Aman, C. Pemeriksaan Kandungan Logam Merkuri, Timbal, dan Kadmium dalam Daging Rajungan Segar yang Berasal dari TPI Gabion Belawan Secara Spektrofotometri Serapan Atom. Maj. Kedokt. Nusant. 2008, 41.

10. Sukender, K.; Jaspreet, S.; Sneha, D.;
Munish, G. AAS estimation of heavy metals and trace elements in Indian herbal cosmetic preparations. Res. J. Chem. Sci. 2012, 2, 46-51.

11. Allen, L. B.; Siitonen, P. H.; Thompson, H. C. Methods for the determination of arsenic, cadmium, copper, lead, and tin in sucrose, corn syrups, and high-fructose corn syrups by inductively coupled plasma atomic emission spectrometry. $J$. Agric. Food Chem. 1997, 45, 162-165.

12. Boevski, I.; Daskalova, N.; Havezov, I. Determination of barium, chromium, cadmium, manganese, lead and zinc in atmospheric particulate matter by inductively coupled plasma atomic emission spectrometry (ICP-AES). Spectrochim. Acta Part B At. Spectrosc. 2000, 55, 1643-1657.

13. Zougagh, M.; de Torres, A. G.; Pavón, J. C. Determination of cadmium in water by ICP-AES with on-line adsorption preconcentration using DPTH-gel and TSgel microcolumns. Talanta 2002, 56, 753761.

14. Espinosa Almendro, J. M.; Bosch Ojeda, C.; Garcia de Torres, A.; Cano Pavón, J. M. Determination of cadmium in biological samples by inductively coupled plasma atomic emission spectrometry after extraction with 1,5-bis(di-2pyridylmethylene) thiocarbonohydrazide. The Analyst 1992, 117, 1749-1751.

15. Noviarty, S. F.; Nugroho, A. Penentuan kandungan unsur $\mathrm{Hg}, \mathrm{Cr}$ dan $\mathrm{Cd}$ dalam bahan paduan logam menggunakan spektrometri ICP-AES. In Seminar Pengelolaan Perangkat Nuklir; PTBNBATAN: Serpong, 2007.

16. Saryati, W. Aplikasi voltametri untuk penentuan logam berat dalam bahan lingkungan. Pus. Teknol. Bahan Ind. Nukl. PTBIN BATAN 2007.

17. Wang, J. Analytical electrochemistry; John Wiley \& Sons, 2006;

18. Rahayu, S. S. Bahan Non Metal-Grafit Available online: http://www.chem-istry.org/materi_kimia/kimiaindustri/utilitas-pabrik/bahan-non-metalgrafit/ (accessed on Sep 7, 2012).

19. Karundeng, M.; Hartati, Y. W.; Tjokronegoro, R. K. Optimasi penentuan kadmium (II) secara differential pulse voltammetry menggunakan elektrode grafit pensil 2013.

20. Day, R. A.; Underwood, A. L. Analisa Kimia Kuantitatif Edisi Ke-5; Erlangga: Jakarta, 1992; 
21. Sitorus, Y. E. Analisis nikel (II) secara voltametri menggunakan elektroda pasta karbon termodifikasi dimetilglioksim (DMG). Sripsi, Universitas Sebelas Maret: Surakarta, 2005. 